Pesq. Vet. Bras. 31(4):350-354, abril 2011

\title{
Evaluation of tear production with modified Schirmer tear test-1 during the neonatal period in cats ${ }^{1}$
}

\author{
Luciano Fernandes da Conceição², Alexandre Pinto Ribeiro², Maria Lucia \\ Marcucci Torres ${ }^{3}$, Maria Lucia Gomes Lourenço ${ }^{3}$ and José Luiz Laus² ${ }^{*}$
}

\begin{abstract}
Conceição L.F., Ribeiro A.P., Torres M.L.M., Lourenço M.L.G. \& Laus J.L. 2011. Evaluation of tear production with modified Schirmer tear test-1 during the neonatal period in cats. Pesquisa Veterinária Brasileira 31(4):350-354. Departamento de Clínica e Cirurgia Veterinária, Faculdade de Ciências Agrárias e Veterinárias, Universidade Estadual Paulista, Via de Acesso Professor Paulo Donato Castellane s/n, Jaboticabal, SP 14870-000, Brazil. E-mail: jllaus@ fcav.unesp.br

The study aimed to evaluate tear production by means of modified Schirmer tear tes-1 (mSTT-1) in neonate cats. Likewise, correlation between mSTT-1 and STT-1 was assessed in vitro. Standard SST strips were cut in half and after eye lid opening, tear production of neonates $(n=15)$ was daily measured in both eyes (mSTT-1), until the 7th day, and at day 14,21 , and 28 . Animals were daily weighted until 28 days of age. Results were compared statistically $(P<0.05)$. During the first 7 days, the overall mSTT- 1 mean was 0.76 wetting/ minute. Significant differences between right and left eyes were not observed at any time point $(P=1.00)$. Tear secretion increased significantly, from the $14^{\text {th }}$ to $28^{\text {th }}$ day, in comparison with 7 first days $(P<0.05)$. Positive correlation between maturity parameters and tear secretion was observed $(P<0.0001)$. Distance between slopes of each strip changed significantly $(P<0.0001)$. It was concluded that tear secretion in the neonatal period of cats is very below the reference values described for young and adults of the same species. It is not possible to extrapolate results obtained with $\mathrm{mSTT}-1$ to standard STT-1.
\end{abstract}

INDEX TERMS: Ophthalmic semiotechnique, standardization, tear production, Schirmer tear test, cats.

RESUMO.- [Avaliação da produção lacrimal pelo teste da lágrima de Schirmer-1 modificado durante o período neonatal em gatos.] Objetivou-se avaliar a produção lacrimal, por meio do teste da lágrima de Schirmer-1 modificado (TLS-1m) em gatos neonatos. Outrossim, estabelecer in vitro a existência de correlação entre o TLS e o TLS-1m. Tiras padronizadas para realização do TLS foram partidas ao meio e após a abertura das pálpebras, a produção lacrimal dos neonatos $(n=15)$ foi aferida em ambos os olhos (TLS-1m), diariamente, até o sétimo e aos 14, 21 e 28 dias. Os animais foram pesados diariamente até os 28 dias de idade. Os resultados foram comparados estatisticamente $(p<0,05)$. Durante

\footnotetext{
${ }^{1}$ Received on July 21, 2010.

Accepted for publication on January 26, 2011.

${ }^{2}$ Departamento de Clínica e Cirurgia Veterinária, FCAV/Unesp, Via de acesso Professor Paulo Donato Castellane s/n, Jaboticabal, SP $14870-$ 000, Brazil. "Corresponding author: jllaus@ fcav.unesp.br

${ }^{3}$ Curso de Medicina Veterinária, Centro Universitário da Fundação de Ensino Octávio Bastos, Avenida Dr. Octávio Bastos s/n, Jardim Nova São João, São João da Boa Vista, SP 13870159, Brazil.
}

os primeiros sete dias de avaliação, a média geral obtida pelo TLS- $1 \mathrm{~m}$ foi de $0,76 \pm 0,08 \mathrm{~mm} /$ minuto. Não se constatou diferença significativa entre os olhos direito e esquerdo, em nenhum dos períodos avaliados $(p=1,00)$. A produção lacrimal elevou-se significativamente, do $14^{\circ}$ até o $28^{\circ}$ dia, comparativamente aos primeiros sete dias $(p<0,05)$. Observou-se correlação positiva entre parâmetros de maturidade e a produção lacrimal $(p<0,0001)$. A distância entre as linhas de cada tira foi significativa $(p<0,0001)$. Conclui-se que a produção lacrimal no período neonatal em gatos é bem inferior aos valores de referência descritos para adultos e jovens da mesma espécie. Não é possível extrapolar valores obtidos com o TLS-1 modificado para o TLS-1 padrão.

TERMOS DE INDEXAÇÃO: Semiotécnica oftálmica, padronização, produção lacrimal, teste da lágrima de Schirmer, felino.

\section{INTRODUCTION}

The preocular tear film is composed of three layers: one outermost consisted of lipids produced by the tarsal glands 
(Meibominas glands), one intermediate aqueous layer secreted by the orbital gland $(60 \%)$ and by the third eyelid gland (40\%), and a deepest one, which consists of hydrated glycoprotein mucin (Ribeiro et al. 2008). All components of this trilaminar fluid are essential to maintain ocular health, and when the secretion of one or more layers is impaired, permanent damage to the cornea due to severe keratoconjuntivitis may arise (Ribeiro et al. 2008).

The Schirmer tear test-1 (STT-1) was developed by Otto Schirmer one century ago (Williams 2005), and is performed by inserting a special paper strip into the conjunctival fornix for one minute with results reported in millimeters per minute (Ribeiro et al. 2008). The STT-2 evaluates basal tear production after topical application of an anesthetic and is of predictive values in animals with corneal ulceration which do not tolerate STT-1 (Ribeiro et al. 2008). In accordance to Williams (2005), in one minute, the wetting of the strip is related only to residual pre-existing tears in the conjunctival fornix, being necessary four additional minutes to accurately evaluate tear reflex production. However, the one minute SST-1 remains the standard test to assess tear production in veterinary ophthalmology (Silva \& Galera 2004, Cullen et al. 2005a, Hartley et al. 2006, Grahn et al. 2005, Lim \& Cullen 2005).

The orbital lacrimal gland and the gland of the third eye lid are derived from the surface of the ectoderm in midembryogenesis, while in humans lacrimal glands develop in the fourth month. They are tubuloacinar structures and are innervated by parasympathetic and sympathetic nerves, and the aqueous tear secretion is regulated primarily via the parasympathetic nervous system (Grahn \& Storey 2004).

In cats, abnormalities associated with the impairment of tear production are less frequent in comparison to dogs. Nevertheless, anesthetic procedures (Cullen et al. 2005), topical instillation of tropicamide (Margadant et al. 2003), corneal sequestra (Cullen et al. 1999) and feline herpesvirus type 1 infection (Lim \& Cullen 2005, Lim et al. 2007, 2009) may deteriorate quality and quantity of the tear film.

In the past there had been a general belief that lacrimation was absent or minimal during the first weeks of life (Toker et al. 2002). It has been established in humans that over $80 \%$ of the infants secreted a normal amount of tears and premature infants also had the capacity to secrete tears (Cullen 1964, Patrick 1974). Toker et al. (2002) observed that tear production in newborns depends on the maturity of the infants, increasing substantially during the neonatal period. The term neonate is derived from the Latin natus (been born) and refers to a newborn during the first four weeks of life (Grundy 2006). In dogs, only one study published in form of an abstract, reported the profile of tear production in neonates with an average age of 25 days (Silva \& Galera 2004). However, the same authors did not measure tear production from the opening of the palpebral fissure on until the completion of the neonatal period. It has been shown that tear secretion in the Saanen breed of goats increases significantly until 180 days of age (Ribeiro et al., 2010).
In cats, no study regarding tear production during the neonatal period has been carried out. Thus, the objectives of the present article were to quantify tear production by means of a modified Schirmer tear test- 1 (with standard strips cut in half) in newborn kittens, from the eyelid opening till the end of the neonatal period, and to determine in vitro whether the uptake of saline solution of the cut STT strips correlates with the uptake of the standard STT strips.

\section{MATERIALS AND METHODS}

This study was approved by the Ethics Committee on Animal Experimentation of the University Center of the Octávio Bastos Foundation Teaching, São João da Boa Vista/SP, Brazil, and followed the ethical guidelines of the Association for Research in Vision and Ophthalmology (ARVO; National Institutes of Health, Publications no.85-23. revised 1985).

Three female (average age of 2 years and mean weight of $3.47 \pm 0.44 \mathrm{~kg}$ ) and one male (average age of 3 years and weighing $4.2 \mathrm{~kg}$ ) Domestic Short Hair cat, bred in a shelter at the University Center of the Octávio Bastos Foundation Teaching, without history of ocular or systemic illness confirmed after clinical, ophthalmic and hematological evaluation, were enrolled in the study. Once selected, females were kept in individual cages, one close to each other, and received commercial dry food and water ad libitum. All of the three females synchronized the oestrus and mating occurred in a natural fashion. After 65 days of pregnancy, two queens delivered kittens within a 12 hour interval; while the third queen delivered 28 hours later (67 days of pregnancy). Fifteen newborn kittens (6 males and 9 females), weighing on birth about $280 \mathrm{~g}$ were used in the study.

After eyelid opening, basal tear production was assessed in both eyes by means of modified Schirmer tear test-1, with a commercial $5.0 \mathrm{~mm}$ strip ${ }^{4}$ cut in half with a $\mathrm{n}^{\circ} 15$ scalpel blade, over a clean metal table. Tear production and the weight of kittens were daily measured for 7 days, and at day 14,21 , and 28 . The time taken to open the eyelids and its impact over tear secretion was also evaluated. Values of $\mathrm{mSST}-1$ below $1 \mathrm{~mm} /$ minute were calculated with a rule, by subtracting the $1 \mathrm{~mm}$ standard mark from the moistened part of the strip. All measurements occurred at the same time $(5: 00 \mathrm{pm})$ and environment, and were performed by the same investigator.

The wetting capacity per minute of the $5.0 \mathrm{~mm}$ standard strip $(n=4)$ and the $2.5 \mathrm{~mm}$ cut strip $(n=4)$ were in vitro assessed, in order to evaluate the reliability of the modified STT-1 used in our study.

Five different volumes of $0.9 \%$ saline solution $(3,5,7,9$, and $10 \mu \mathrm{L}$ ) were applied to the notched end of each strip, and mean values obtained for each tested volume were plotted for statistical analysis.

Data were evaluated by nonparametric or parametric repeated measures, followed by Dunn's or Tukey multiple comparison post-hoc test, in accordance with normality distribution. Person's test was used to assess correlation between tear production and maturity parameters. Linear regression models were used to compare the wetting capacity of 5.0 and $2.5 \mathrm{~mm}$ strips. Significance was set at a value of $P<0.05$ for all analyses.

\footnotetext{
${ }^{4}$ Teste de Schirmerâ, Ophthalmos, São Paulo, SP.
} 


\section{RESULTS}

Results are expressed as mean and standard deviation $( \pm S D)$. Throughout the period of evaluation, the lowest and the highest mean \pm SD of the modified STT-1 (mSST-1) were, respectively, $0.60 \pm 0.26$ wetting/minute and $2.14 \pm 1.20$ wetting/minute. Means between right and left eyes of each individual did not change significantly, as well as between males and females evaluated at the same time point $(>0.05)$ (Table 1). From day 14 to day 28, average $\mathrm{mSTT}-1$ increased significantly $(P<0.001)$ (Fig.1); however, average mSST-1 among this period did not change significantly ( $P>0.05)$.

Mean \pm SD eyelid opening time was of $13.73 \pm 1.79$ days. Tear production did not vary significantly among kittens in which palpebral fissure opened at day $12(n=7), 14(n=2)$, $15(n=2)$, and $16(n=4)(P=1.00)$ (Fig.2). During the period of evaluation, both age $\left(r^{2}=0,98 ; P<0.0001\right)$ and weight $\left(r^{2}=0,96 ; P<0.0001\right)$ of neonates showed strong positive correlation with $\mathrm{mSTT}-1$ values (Fig.3).

Average wetting capacity per minute between standard $(5.0 \mathrm{~mm})$ and cut strips $(2.5 \mathrm{~mm})$ differed significantly with volumes of $5-10 \mu \mathrm{L}(P<0.001)$. Although the wetting capacity per minute of the $2.5 \mathrm{~mm}$ strip have reached values $44 \%$

Table 1. Descriptive statistics of the modified Schirmer tear test-1 (wetting/minute) between right and left eyes in neonates of cats, in each time point evaluated

\begin{tabular}{ccccc}
\hline $\begin{array}{c}\text { Days of } \\
\text { evaluation }\end{array}$ & Right eye $^{*}$ & $\begin{array}{c}\text { Confident } \\
\text { interval }\end{array}$ & Left eye* & $\begin{array}{c}\text { Confident } \\
\text { interval }\end{array}$ \\
\hline 1 & $0.67 \pm 0.18$ & 0.10 & $0.69 \pm 0.21$ & 0.11 \\
2 & $0.65 \pm 0.22$ & 0.12 & $0.65 \pm 0.18$ & 0.10 \\
3 & $0.60 \pm 0.26$ & 0.14 & $0.70 \pm 0.19$ & 0.11 \\
4 & $0.74 \pm 0.27$ & 0.15 & $0.70 \pm 0.26$ & 0.14 \\
5 & $0.78 \pm 0.30$ & 0.16 & $0.78 \pm 0.19$ & 0.10 \\
6 & $0.84 \pm 0.18$ & 0.10 & $0.82 \pm 0.20$ & 0.11 \\
7 & $0.88 \pm 0.16$ & 0.08 & $0.96 \pm 0.15$ & 0.08 \\
14 & $1.30 \pm 0.46$ & 0.25 & $1.24 \pm 0.37$ & 0.20 \\
21 & $1.44 \pm 0.50$ & 0.28 & $1.60 \pm 0.63$ & 0.35 \\
28 & $2.08 \pm 1.00$ & 0.55 & $2.14 \pm 1.20$ & 0.66
\end{tabular}

*Dunn's test $(P>0.05)$.

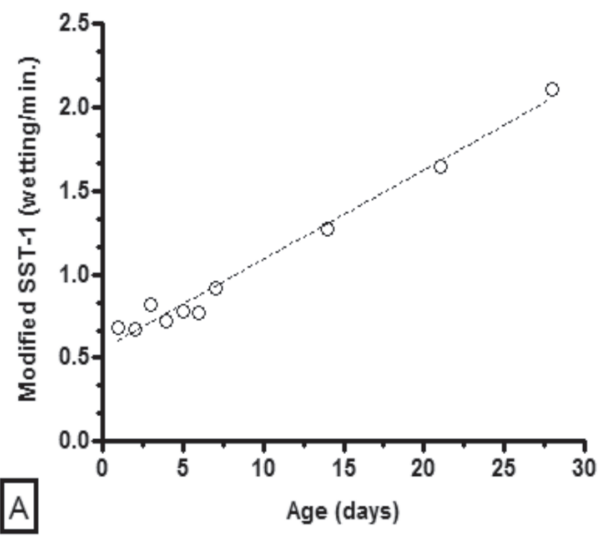

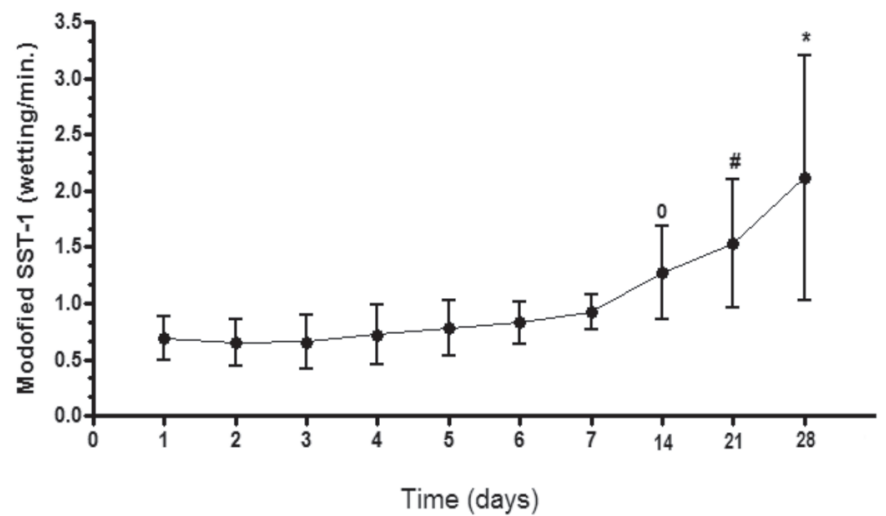

Fig.1. Mean $( \pm S D)$ of modified Schirmer tear test-1 (STT-1) in neonates of cats in all time points evaluated (days). ${ }^{0 \# *}$ Significant in comparison to other time points (Dunn's test $P<0.001)$.

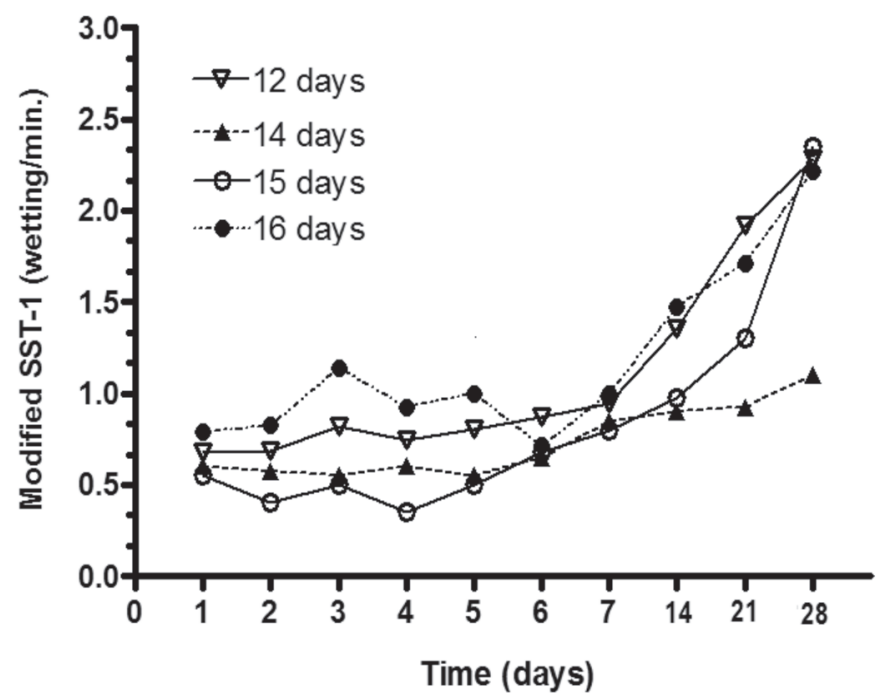

Fig.2. Mean* values of the modified Schirmer tear test-1 (SST1 ) in neonate cats in regard of eye lid opening day. *Dunn's test $(P>0.05)$.

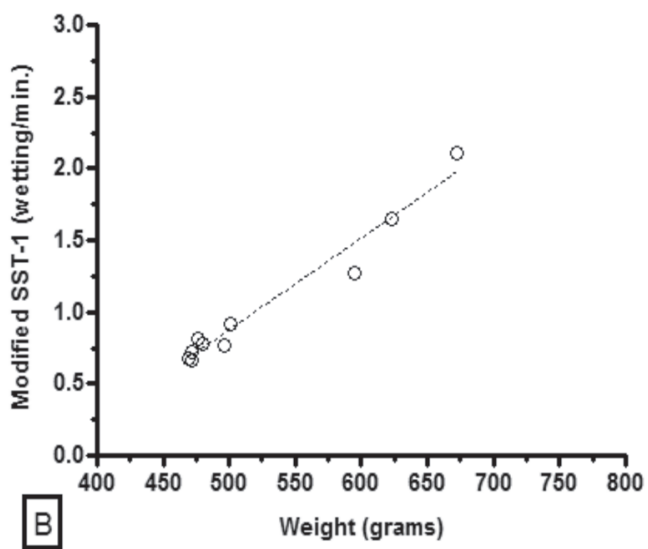

Fig.3. (A) Linear regression curves indicating positive correlation between tear secretion (wetting/minute) and age (days), and (B) between tear secretion and weight (grams) in neonate cats .

*Person's correlation test $\left(r^{2}=0.98 ; P<0.0001\right)^{\mathrm{a}},\left(r^{2}=0.96 ; P<0.0001\right)^{\mathrm{b}}$. 
Table 2. Descriptive statistics of the In vitro wetting capacity per minute between the cut $(2.5 \mathrm{~mm})$ and the standard strips $(5.0 \mathrm{~mm})$ after instillation of different volumes $(\mu \mathrm{L})$ of $0.9 \%$ saline solution

\begin{tabular}{ccccc}
\hline $\begin{array}{c}\text { Saline solution } \\
(\mu \mathrm{L})\end{array}$ & $0.25 \mathrm{~mm}$ & $\begin{array}{c}\text { Coeficient of } \\
\text { variation(\%) }\end{array}$ & $5.0 \mathrm{~mm}$ & $\begin{array}{c}\text { Coeficient of } \\
\text { variation(\%) }\end{array}$ \\
\hline 3 & $4.50 \pm 0.57^{\#}$ & 12.83 & $2.57 \pm 0.43^{\#}$ & 16.89 \\
5 & $12.50 \pm 1.00^{*}$ & 8.00 & $5.12 \pm 0.25^{\star}$ & 4.88 \\
7 & $18.25 \pm 0.95^{\star}$ & 5.25 & $8.47 \pm 0.55^{\star}$ & 6.49 \\
9 & $23.75 \pm 0.95^{*}$ & 4.03 & $11.25 \pm 0.86^{*}$ & 7.70 \\
10 & $25.50 \pm 0.64^{*}$ & 5.06 & $12.00 \pm 0.81^{*}$ & 6.80 \\
\hline
\end{tabular}

*Tukey test $(P<0.001),{ }^{\#}(P>0.05)$.

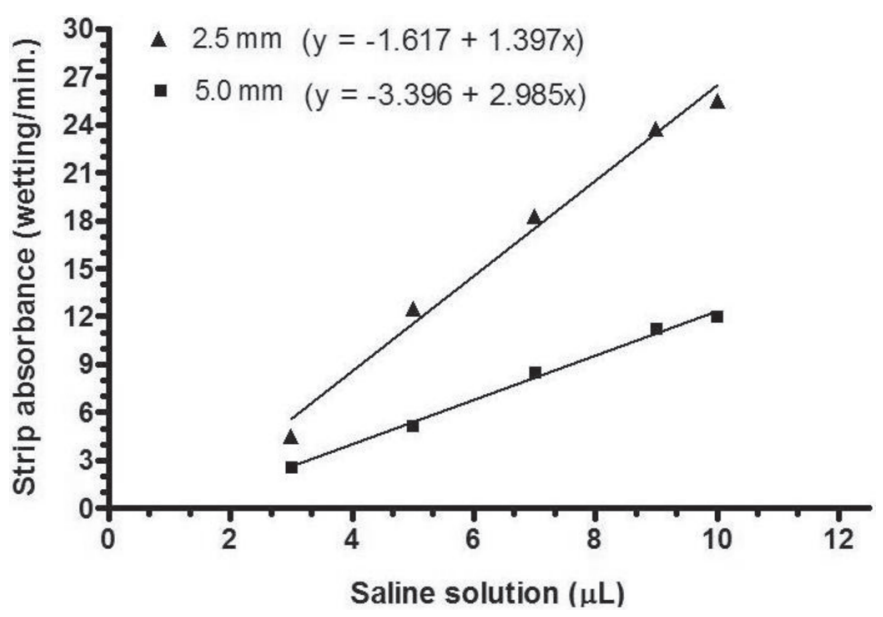

Fig.4. Linear regression curves between strip absorbance (wetting /minute) and volume of saline administered $(\mu \mathrm{L})$. Differences between slopes of $5.0 \mathrm{~mm}$ (squares) and $2.5 \mathrm{~mm}$ (pyramids) strips differed significantly $(P<0.001)$, assuming that there is a $0.02 \%$ chance of randomly choosing data points with slope this different.

higher than the standard strips following $3 \mu \mathrm{L}$ instillation of saline, such difference was not significant ( $P>0.05)$ (Table $2)$. The wetting capacity of both $5.0 \mathrm{~mm}\left(r^{2}=0.99 ; P=0.0002\right)$ and $2.5 \mathrm{~mm}\left(r^{2}=0.98 ; P=0.0006\right)$ strips correlated positively with the enhancement of the volume delivered. However, differences between slopes also differed significantly $(P<0.001)$, assuming that there is a $0.02 \%$ chance of randomly choosing data points with slope this different (Fig.4).

\section{DISCUSSION}

The present study showed that in neonate cats, tear production increases significantly after the 14th day of life $(P<0.001)$. However, values of the modified Schirmer tear test-1 (mSTT-1) observed in our study are very below reference values described for the standard Schirmer tear test (SST) in healthy young and adult cats (Cullen et al. 2005a, Lim \& Cullen 2005, Lim et al. 2009).

In neonate dogs with ages ranging from 22 to 28 days, average SST -1 and SST-2 values are $13.6 \pm 3.07$ wetting/ min., and $3.63 \pm 1.77$ wetting/min., respectively (Silva \& Galera 2004). In the present study, average mSTT-1 value at day $28(2.11 \pm 0.82$ wetting $/ \mathrm{min}$.) was very below the SST1 and STT-2 values observed in dogs of the same age (Silva \& Galera 2004). In human beings, only preterms infants secret lower amount of tears in comparison to term infants (Toker et al. 2002, Akar et al. 2004, Dogru et al. 2004). Considering that at day 15 , the average weight of the kittens was of $469.33 \pm 138.84$ grams (reference values in cats with same age: $240 \pm 10 \mathrm{~g}$ ), and that the three queens used in the study labored in periods considered normal for cats $(66.00 \pm 1.47$ days of pregnancy), is reasonable to admit that newborn kittens were not preterms (Johnston et al. 2001, Grundy 2006).

In this research, average time for eyelid opening was of $13.73 \pm 1.79$ days, which can be assumed as physiological for this species (Grundy 2006). Although at day 28, animals that opened their eyelids at day 14 have shown decreased STT-1 values $(1.10 \pm 0.28$ wetting $/ \mathrm{min})$, in comparison to other kittens, in which the eyelid opening occurred at day $12(2.27 \pm 0.78$ wetting $/ \mathrm{min}$.), 15 (2.35 \pm 1.13 wetting/ $\mathrm{min})$, and $16(2.21 \pm 0.834 \mathrm{wetting} / \mathrm{min}$.), average values of modified SST-1 did not change significantly throughout the study $(P=1.00)$.

The positive correlation observed between tear production and parameters related to maturity, such as age $\left(r^{2}=0.98 ; P<0.0001\right)$ and weight $\left(r^{2}=0.96 ; P<0.0001\right)$, suggests that anatomical components responsible for tear secretion are not completely developed in newborn kittens. In human beings, two different studies reported that tear production correlates positively with the weight of the babies, but not with the post-conceptional ages of the full term neonates (Toker et al. 2002, Rohatgi et al. 2005), whereas in another study, the opposite was noted (Akar et al. 2004). The amount of light that reaches the retina and the status of corneal innervation are variables that also contribute to tear secretion (Cullen et al. 2005b). Therefore, the lower corneal sensitivity threshold, in addition to the underdeveloped retina of neonates, may also be associated with the low STT-1 values observed in this study (Lavely 2006, Bedford 2009).

Harley et al. (2005) showed that STT-1 values of dogs increase in the amount of $0.7 \mathrm{~mm}$ at the afternoon (16:00p.m.), in comparison with values collected in the morning (10:00a.m.). Hence, one may considerate that time of the day did not play an important role over the STT measurements taken in this research, once all the exams were performed at the same time of day (5:00p.m.). Differences between gender were not observed herein $(P=0.84)$, which corroborates with findings of one study where dogs were used (Hartley et al. 2006). Regarding morphometric analysis of lacrimal glands, bitches present smaller glands than male dogs (Cabral et al. 2005). However, it is believed that such variable did not interfere in the modified SST-1 values in present study, due to underdeveloped gonades of cats during the neonatal period (Johnston et al. 2001).

Due to small palpebral fissure of neonates, it was decided to cut in half the $5.0 \mathrm{~mm}$ standard strips to perform 
the modified STT-1. From the in vitro study, it can be assumed that the smaller area of the $2.5 \mathrm{~mm}$ cut strips allowed increased values of STT-1, compared with the $5.0 \mathrm{~mm}$ standard strips. For all tested volumes, values regarding the wetting absorbance of the standard $5.0 \mathrm{~mm}$ strip observed in this study, were a little higher than previous results described in another in vitro study (Williams 2005). Yet, from our in vitro results, it may be speculated that after eyelid separation, the amount of tears accumulated in the conjunctival fornice during the neonatal period of cats is less than $3 \mu \mathrm{L}$. However, during the experiment with neonates, one cannot be sure what level of tears was lost through the nasolacrimal duct and by tear evaporation.

Anesthetic procedure (Cullen et al. 2005) and instillation of tropicamide (Margadant et al. 2003) deteriorate quantitatively tear secretion in cats. In addition, corneal sequestra, feline herpes virus type 1 (FHV-1), Chammidophola and Mycoplasma infection may produce qualitative tear film abnormalities, principally because the impaired secretion of mucin, which may be attributed to conjunctival scamous metaplasia, inflammation and a decreased amount of conjunctival goblet cells (Cullen et al. 1999, Lim \& Cullen 2005, Lim et al. 2009). In one study, despite the impaired quality of the tear film, assessed by means of tear film break up time and conjunctival biopsies, Lim et al. (2009) showed that STT-1 values increased significantly in young cats inoculated experimentally with $\mathrm{FHV}-1$. Considering our results, further studies evaluating possible correlations between SST-1 and -2 and the stability of the tear film by means of evaluation of tear film break up time in neonate cats are warranted.

In summary, it is concluded that baseline tear production in neonates cats, evaluated by means of the modified Schirmer tear test-1, are really diminished in comparison of values reported in the current literature for adult and young subjects of the same species. Likewise, tear secretion increases in parallel with age and weight, notably 14 days after the eyelid opening. It is not possible to extrapolate results obtained with $\mathrm{mSTT}-1$ to standard STT-1.

\section{REFERENCES}

Akar Y., Cira A., Apaydin C., Erman M.A. \& Yilmaz A. 2004. The effect of prematurity on tear production. Curr. Eye Res. 28(2):145-151.

Bedford P.G.C. 2009. Afecções da retina, p.169-189. In: Laus J.L. (Ed.), Oftalmologia clínica e Cirúrgica em Cães e em Gatos. Roca, São Paulo.

Cabral P.V., Laus J.L., Zaidan D.M.L., Tadeu P.G., Carmen T.I., Raposo M.O. \& Mamede F.V. 2005. Canine lacrimal and third eyelid superficial glands macroscopic and morphometric characteristics. Ciência Rural 35(2):391-397.
Cullen C.L., Njaa B.L. \& Grahn B.H. 1999. Ulcerative keratitis associated with qualitative tear film abnormalities in cats. Vet. Ophthalmol. 2(3):197-204.

Cullen L.C., Lim C. \& Sykes J. 2005a. Tear film breakup times in young healthy cats before and after anesthesia. Vet. Ophthalmol. 8(3):159165.

Cullen L.C., Ihle S.L., Webb A.A. \& McArville C. 2005b. Keratoconjunctival effects of diabetes mellitus in dogs. Vet. Ophthalmol. 8(4):215-224.

Dogru M., Karakaya H., Baykara M., Ozmen A., Koksal N., Goto E., Matsumoto Y., Kojima T., Shimazaki J. \& Tsubota K. 2004. Tear function and ocular surface findings in premature and term babies. Ophthalmol. 111(5):901-905.

Grahn B.H. \& Storey E.S. 2004. Lacrimomimetics and lacrimostimulants. Vet. Clin. North Am., Small Anim. Pract. 34(3):739-753.

Grahn B.H., Sisler S. \& Storay E. 2005. Qualitative tear film and conjunctival goblet cell assessment of cats with corneal sequestra. Vet. Ophthalmol. 8(3):197-170.

Grundy S.A. 2006. Clinically relevant physiology of the neonate. Vet. Clin. North Am., Small Anim. Pract. 36(3):443-459.

Hartley C., Williams D.L. \& Adams J. 2006. Effect of age, gender, weight, and time of day on tear production in normal dogs. Vet. Ophthalmol. 9(1):53-57.

Johnston S.D., Kustritz M.V.R. \& Olson P.N.S. 2001. Feline pregnancy, p.414-430. In: ibid. (Eds), Canine and Feline Theriogenology. W.B. Saunders, Philadelphia.

Margadant D.L., Kirkby K., Andrew S.E. \& Gelatt K.N. 2003. Effect of topical tropicamide on tear production as measured by Schirmer's tear test in normal dogs and cats. Vet. Ophthalmol. 6(4):315- 320.

Lavely J.A. 2006. Pediatric neurology of the dog and cat. Vet. Clin. North Am., Small Anim. Pract. 36(3):475-501.

Lim C.C. \& Cullen C.L. 2005. Schirmer tear test values and tear film break-up times in cats with conjunctivitis. Vet. Ophthalmol. 8(5):305310.

Lim C.C., Christopher M.R., Thomasy S.M., Kass P.H. \& Maggs D.J. 2009. Effects of feline herpesvirus type 1 on tear film break-up time, Schirmer tear test results, and conjunctival globlet cell density in experimentally infected cats. Am. J. Vet. Res. 70(3):394-403.

Ribeiro A.P., Brito F.L.C., Martins B.C., Mamede F. \& Laus J.L. 2008. Qualitative and quantitatives tear film abnormalities in dogs. Ciência Rural 38(2):568-575.

Ribeiro A.P., Piso D.Y.T., Padua I.R.M., Silva M.L., Laus J.L. 2010. Intraocular pressure and tear secretion in Saanen goats with different ages. Pesq. Vet. Bras. 30(9):798-802.

Rohatgi J., Gupta V.P., Mittal S. \& Faridi M.M. 2005. Onset and pattern of tear secretions in full-term neonates. Orbit 24(4):231-238.

Silva E.G. \& Galera P.D. 2004. Evaluation of tear formation during neonatal period in small breed dogs, using the Schirmer tear test: STT1 \& STT2 (Abstract). Annual Meeting of the American College of Veterinarian Ophthalmologists, Washington, DC. Vet. Ophthalmol. 7(6):437-453.

Toker E., Yenice Ö., Ögüte M.S., Akman I. \& Özek E. 2002. Tear production during the neonatal period. Am. J. Ophthalmol. 133(6):746749.

Williams D.L. 2005. Analysis of tear uptake by the Schirmer tear test strip in the canine eye. Vet. Ophthalmol. 8(5):325-330. 